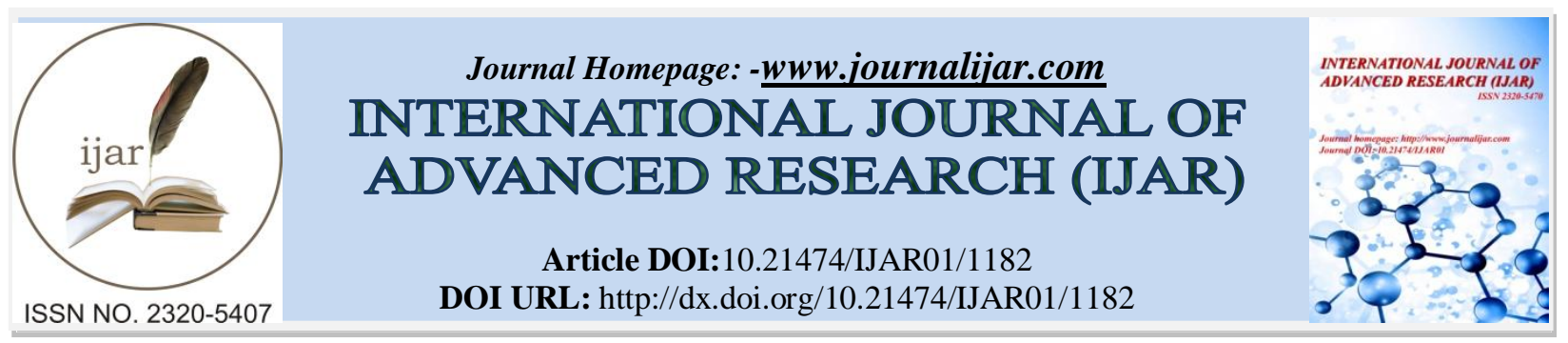

RESEARCH ARTICLE

\title{
USES OF SOME MEDICINAL AND AROMATIC PLANTS IN THE LANDSCAPE ARCHITECTURE GROWN IN THE LAKES DISTRICT.
}

\author{
Şirin DÖNMEZ \\ Süleyman Demirel University, Faculty of Architecture, Department of Landscape Architecture, Isparta, Turkey.
}

\section{Manuscript Info}

Manuscript History

Received: 15 June 2016

Final Accepted: 19 July 2016

Published: August 2016

Key words:-

Medicinal and aromatic plants,

landscape design, planting design, Lakes

District

\begin{abstract}
Medicinal plants can be considered in different areas such as spices, medicine industry, beverage, perfume, soap, candy, cosmetic, toothpaste, chewing-gum, tea and essence. Medicinal plants used both for ornamental and for benefit in the traditional houses and the gardens. Nowadays, medicinal plants are included at many of thematic parks and they are interested by the humanity. However, most of these plants are not known and not used commonly in planting design.
\end{abstract}

In the study, utilization of some medicinal and aromatic plants in landscape architecture, which was exported from Lakes District covering Antalya, Isparta and Burdur cities, have been investigated. Thus, exporting 12 plants and other plant species belonging to same genus have been determined. Totally, 69 plants have been evaluated by taking into consideration eleven parameters according to utilization form in landscape architecture. Consequently, it has been found that there are 8 plants (Lavandulastoechas, Thymus revolutus, Thymus cherlerioidesvar.cherlerioides, Thymus longicaulissubsp.chaubardii, Salvia caespitosa, Salvia chrysophylla, Myrtuscommunis, Cyclamen mirabile) having six or more properties due to utilization in planting design. Moreover, suggestions about the using of these plants in landscape architecture have been improved.

Copy Right, IJAR, 2016,. All rights reserved.

\section{Introduction:-}

Despite the significant progresses in the field of medicine in today's world, humankind had looked for the healing and cure in the nature from time to time and with the hundred years of experience continued to the use of medical herbs. Medical and aromatic herbs, both with their active substances and their ways of consumption have a wide scope. Even though they don't have a standardized classification today, they're usually classified according to their family, their active substances, their consumption and usage, their benefits-received organs and their pharmacological effects [1,2].

\section{Corresponding Author:-Şirin DÖNMEZ}

Address:-Süleyman Demirel University, Faculty of Architecture, Department of Landscape Architecture, Isparta, Turkey. 
With the emergence of the side effects of the medicines, especially chemical and synthetical ones that are used in the treatment of diseases, the usage of medical herbs increased. Medical and aromatic herbs are used in various fields such as spices, pharmaceuticalindustry, beverages, perfumes, soaps, confectionery, cosmetics, tooth pastes, gums, healing and relaxing teas, scents, flavors etc. As a result of the constant increase of demand to these herbs, a separate market for their trade has been formed $[3,4]$.

However, because supply of the medical and aromatic herbs are usually provided via aggregation from the nature, with the heavy demand some plant species are extincted or are in danger of extinction. In order to preserve and sustain the existence of plant species, these species should be included in the landscaping projects [5].

Thus, the herbs of the regulated region will be protected and their extinction will be prevented and also this will contribute to the formation of a regional medical and aromatic plant species collection. The usage of the herbs for the benefits of the humankind has an old history. Herbs, which are once used with the aggregation from the wild nature, started to be cultivated in the gardens when humans started to form permanent settlements. In the beginning, plants were cultivated for the purpose of nutrition then as their curative features got discovered; they began to be cultivated for the purpose of medicine making. These gardens, also named as the "Medical Plants Garden" were highly common in Medieval Europe (A.D. 500-1200). These gardens were especially established in monasteries and they've also included aromatic herbs [6,7].

In landscape designs, vegetation designs holds and important place and even in some themed parks they become the main component. In the selection of the plants in designs, their aesthetic appearances considered as important as their ecological needs and their functional usage. Color, type and sequence of the leafs, flowers, fruits, branches and crusts of the plants designate their areas of usage and enables the creation of effective compositions.

Especially in today's world where xeriscaping is trending, in vegetation, instead of customary cultivated plants the usage of natural plants started to increase. To make us of the regions natural vegetation makes botanical design more efficient as aesthetically and functionally also brings out regional unique designs [9].

In the scope of the study, according to the information above, in order to designate the usage of some medical and aromatic plants, which are known and produced in Lakes Region and cities of Antalya, Burdur and Isparta, in landscape gardening, an evaluation has been conducted and prominent plants have been examined in detail.

Geographical, economic and cultural factors are determining the borders of the Lake Region. Region's explicit geographical feature is the lakes. It gets its name from the many large and small lakes it contains. Acigöl, Burdur Lake, Eğirdir Lake, Beyşehir Lake, Söğüt Lake, Salda Lake veKestel Lake are in this region [10].

Lake Region resembles the Inner Aegean Anatolian region in terms of climate but it's also under the influence of the Mediterranean climate. Precipitation of the spring season is about the same as the winter season. Summer drought is softer than Mediterranean climate. Lake Region's climate is a transition area to the Central Anatolia's climate. Also number of the days with hail here is close to Central Anatolia's to some extent but is much bigger compared to Mediterranean shore [11,12].

Ethno botanical studies conducted in Lakes Region shows the existence of various regional medical and aromatic herbs in the region. However, very few of these were subjected to biochemical studies and proven to be utilizable medically. Thus, the plants that are received for consideration are the ones mentioned in the report named "Medical and Aromatic Plants Sector" published by Western Mediterranean Development Agency and the ones that are exported [13].

Salvia (Sage) and Laurusnobilis(bay) from the evaluated plants are known to have antioxidant and antibacterial features $[14,15]$.

In addition to this, studies have shown that the plants of Galanthus (snowdrop), Rhuscoriaria (sumac), Pimpinella (anisee), Cistus (rockrose), Juniperus (juniper), Ceratoniasiliqua(carob), Ruscusaculeatus (butcher's broom), Ballotacristata, Lavandulastoechas(lavender), Origanum, Thymus (thyme), Myrtuscommunis (mrytle), Cyclamen (sowbread) are used in treatments of internal diseases and respiratory tract infections $[16,17,18,19,20,21]$. 


\section{Material and Method:-}

Considering the medical and aromatic plants that are exported in the Lakes Region, 12 plants come into prominence. In the scope of the conducted study, in addition to the exported species, other species from the same kind and are deployed in the region that can be used in landscape architecture are also mentioned. In this scope, visual and aesthetic features of total of 69 plants from 11 families are evaluated [22].

While determining the evaluation parameters, flower, leaf and fruit features of the plants, their scents and their alternative usage facilities other than botanical compositions in landscape architecture are taken into consideration. Total of 11 parameters are determined and their selection criterias are listed below in order.

- Endemic: Rather they are endemic to Turkey or not

- Ornamental Flower: Suitable to use in landscape architecture in terms of florescence structure, number and sequence

- Ornamental Leaf: Color of the leaf, its being attractive in vegetation period and in autumn

- Ornamental Fruit: its being attractive in terms of structure, size and color

- Aromatic: Leaf, flower and fruits having a nice scent concretely

- Perennial: In order to spread its usage in design

- Evergreen: Especially for the suitability in winter landscape, its leafs being evergreen

- Solitary Usage: Its being attractive and suitable to solitary usage in terms of trunk, brunches and sequence

- Usage in Flower Parterre: Suitability in usage in parterres in terms of flower features and florescence duration

- Usage as groundcover: Having the feature of ground cover

- Usage in rock gardens: Suitability to grow in rocky and stony fields

In accordance with the obtained data, proposals brought forward about the usage of plants with 6 or more than 6 features in landscape architecture.

\section{Result and discussion:-}

Considering the medical and aromatic plants that are exported in the Lakes Region, 14 plants come into prominence. In the scope of the conducted study, considering the other species from the same kind and are deployed in the region, visual and aesthetic features of total of 69 plants from 11 families are evaluated (Figure 1).

When these obtained indications are analyzed;

- It is estimated that number of the plants having 1 feature is 4 , number of the plants having 2 features is 6 , number of the plants having 3 features is 14, number of the plants having 4 features is 27 and number of the plants having 5 features is 10 . Here, the maximum number of plants is gathered in 4 features.

- Number of plants having 6 or more than 6 features in other words that are more suitable in landscape usage is 8 .

- $\quad$ Plants belong to Lamiaceae family with the max percentage of 66,6.

- Percentage of endemic plants is 37,6 and $95,6 \%$ of plants are perennial.

- Aromatic feature is the most prominent parameter. In this context, $69,5 \%$ of the plants in the study have this feature.

- Second prominent feature is to possess ornamental flowers. $43,4 \%$ of the plants have this feature.

- In the evaluated plants, the least seen feature is to possess ornamental leafs. 7,2\% of the plants have this feature.

- Plants have the most utilization potential in rock and stone gardens with $63,7 \%$ other than the botanical compositions while the least utilization potential in solitary usage.

As a result of the evaluations made under the scope of the study, 8 plants come into prominence. From these plants, Lavandulastoechasa plant with purple colored flowers and a nice scent is used is plantation designs. It's especially quite suitable for solitary usage because it has long florescence period and thick branching feature.

From other prominent plants, Thymus revolutus, Thymus cherlerioides, Thymus longicaulissubsp.chaubardiiare important as they are endemic and that provides unique botanical designs and preservation of those designs. However, these are not well-known and commonly-used. This study shows that these types are suitable for utilization in flower parterres and rock gardens as they have both ornamental flowers and nice scents. 
Even though there are 22 sage species that are deployed in Lakes Region, they're not commonly used in designs in that region. All of the sage species that are evaluated under the scope of this study are suitable for designs with the possession of at least 2 features from the list mentioned. Prominent ones, Salvia caespitosa and Salvia chrysophyllawith their ornamental flowers, nice scents and their ability to grow in rocky-grizzard areas can easily be used in designs. Plus, their endemic feature makes them important and special.

Myrtuscommunis which has a very wide area of utilization in landscape architecture is stated as an important specie in the study. While it can create an accent effect when it's used as a batch, it can also be used as a hedge plant. Its nice scented flowers can be used in removing unpleasant smells.

The last prominent plant of the study is Cyclamen mirabile. It's one of the rare ones of the examined species because it owns ornamental leafs. With its ornamental flowers and leafs, it is not only suitable for usage in flower parterres but also in flowerpots and roof gardens. 
Figure 1:-Visual characteristics of some medicinal and aromatic plants growing in Lake district and their use in planting design.



Not: Plants that have six or more features are indicated in gray. 
Figure 1(continued):- Visual characteristics of some medicinal and aromatic plants growing in Lake district and their use in planting design.



Not: Plants that have six or more features are indicated in gray.

\section{Conclusion:-}

Different micro-climates of Lakes Region enable the increase of the species diversity of the plants. Conducted ethno botanical studies show that a lot of species are used with medical purposes by the locals. However very few of these are cultivated and getting produced. Cultivation of these plants and their usage in landscape architecture are 
very important in order to create a general knowledge about them and prevent them from extinction. It is inevitable in today's world for the preservation of the plants which are under a lot of stress because of numerous factors such as the climatic factors, senseless aggregation and uncoordinated structuring.

\section{References:-}

1. Van Overwalle G. 2007. Intellectual property protection for medicinal and aromatic plants, Medicinal and Aromatic Plants, Capter 9, Springer, vol 121-128.

2. Faydaoğlu E, Sürücüoğlu M. 2011. From Past to Present, The Usage of Medical and Aromatic Herbs and Their Economic Importance, Kastamonu University, Magazine of Faculty of Forestry

3. Bayramoğlu M M, Toksoy D, Şen G. 2009. Medical Plant Trade in Turkey, Socio-Economic Problems in Forestry, SüleymanDemiral University, Isparta.

4. Yaldız G, Yüksek T, Şekeroğlu N. 2010. Importance of the Medical and Aromatic Herbs in the Reconstruction of Rize's Forest and Coast Villages, 3rd International Black Sea Forestry Congress, Rize, Volume:3, $176-186$.

5. Kevseroğlu K, Uzun A, Çalışkan V. 2014. Medical and Aromatic Herbs Detected in The Natural Flora of Middle and East Black sea Region, 2nd Medical and Aromatic Herbs Symposium, Yalova, 108-117

6. Leszczynski A N. 1997. Planting The Landscape A Professional Approach to Garden Design. John Wiley and Sons. İnc. Nev York. 205 p.

7. Arslan M. 2010. Usage Facilities of Medical and Aromatic Herbs in Landscape Architecture, 4th Ornamental Plants Congress Proceedings Book, Alata Garden Cultivations Research Institution, Erdemli/Mersin, $265-270$.

8. Seyidoğlu N. 2009. Researchs on the Usage and Production of Some Geophytes in Landscape Regulations, Doctoral Thesis, Istanbul University, Institute of Science and Technology, Istanbul.

9. Güner A. 2009. NezahatGökyiğit. Botanical Garden Travel Guide. Express Pres, 46p, İstanbul.

10. Karaduman N. 1997. Role of the Development Centers in Regional Progress, Lakes Region Manifacturing Industry Implementation. İstanbul University, Institute of Social Sciences, Doctoral Thesis, İstanbul.

11. Bekçi İ, Usul H. 2001. Financial Problems of the Small and Medium-sized Businesses in Lakes Region and Their Solutions, SüleymanDemirel University, Faculty of Economics and Administrative Sciences Pres, 6(1):11-125

12. Kantarc1 M D. 2008. An Ecological Evaluation on the Case and Effects of the Calescence-Aridification Period in Lakes Region. SüleymanDemirel University Faculty of Forestry Magazine, Serial: A, 1-34.

13. BAKA. 2012. Report of Medical and Aromatic Herbs Sector, West Mediterranean Development Agency, p 30

14. Demirtaş A, Öztürk H, Pişkin İ, Demirkıran D, Salgırlı Y, Fidancı U R, Emre B. 2011. Research on the Effects of Extracts of Rosemary and Sage on Ruminial Fermentation with RUSITEC (Rumen Simulation Technique), İstanbul University Veterinary School Magazine. 37 (2), 127-134.

15. Yazıc1 H. 2002. Research on the Usage Facilities of the Leafs and Fruits of Laurel (Laurusnobilis) grows in West Blacksea Region, Doctoral Thesis, ZonguldakKaraelmas University Faculty of Science and Technology, Zonguldak, p 309.

16. Tümen İ. 2004. Chemical Components of the Leafs, Fruits and Cones of Juniperus ssp. Species that Grow in Turkey, Doctoral Thesis, ZonguldakKaraelmas University Faculty of Science and Technology, Zonguldak, p280

17. Zeybek N, Zeybek U. 1994. Pharmaceutical Botany. Ege University Faculty of Pharmacy Pres No.2 İzmir, 436 p.

18. BağdatBahtiyarca R. 2006. Areas of Usage of Medical and Aromatic Plants, Cultivation Techniques of Medical Sage (Salvia Officinalis L.) and the Species Known as Thyme in Turkey. Farm Plants Central Research Institute Magazine, 15 (1):19-28

19. Aydin B D. 2008. Research on the Antibacterial Effect of Some Medical Herbs and Species on Food Pathogenes, Kafkas University Veterinary School Magazine, 14 (1): 83-87.

20. Altay V, Karahan F. 2012. An Ethno Botanical Research about the Plants in and Around of TayfurSökmen Campus (Antakya-Hatay), Blacksea Science and Technology Magazine, 2(7):13-28

21. Güngör İ, Atatoprak A, Özer F, Nihan A, Kandemir İ N. 2002. World of Plants. LazerOfset Pres Ankara, p 384.

22. TUBIVES. 2015. Data System of the Plants of Turkey http://turkherb.ibu.edu.tr/index.php? page $=220$. 